\title{
David Fairchild (1869-1954)
}

\author{
Margaret J. Mustard \\ Department of Biology, University of Miami, Coral Gables, FL 33124-0421
}

David Fairchild, famed plant explorer, was born in 1869 at the Michigan State Agricultural College where his father was a professor of English literature. When he was 10 years old, his father was appointed head of the Kansas State College of Agriculture, where later, as an undergraduate student, Fairchild became acquainted with Walter T. Swingle. Both young men were interested in plant pathology, and a keen friendship developed that lasted throughout their lives. While at Kansas State, Fairchild also met Alfred Russel Wallace, who had worked on the theory of evolution by natural selection. Wallace's eloquent description of the various plants of Java inspired Fairchild to visit the Malay Archipelago. As a graduate student in plant pathology and mycology, he studied and subsequently worked with his uncle, Bryon D. Halstead.

Fairchild later joined the Plant Pathology Section of the U.S. Dept. of Agriculture (USDA). In 1893 he resigned from the USDA to study at the Naples Zoological Station. While en route to Naples, he met Barbour Lathrop, a world traveler interested in the introduction of foreign plants into the United States. This encounter resulted in Lathrop funding and accompanying Fairchild on plant explorations around the world. Their collections led to the establishment of the USDA's Foreign Seed and Plant Introduction Division.

With Fairchild as chief, the division continued to expand. Dedicated plant explorers, among them Swingle, Frank N. Meyer, Wilson Popenoe, and many other prominent horticulturists, brought back more than 54,000 plants, including apricots, willows, apples, muskmelons, iris, and roses from Chinese Turkestan; cherries from Siberia; dates from Egypt and Algeria; German pearcultivars; numerous ornamentals from England; a yellow tropical water lily from East Africa; a giant rose; and many clones of mango and avocado now important to Florida's industry. In 1923 Fairchild continued his plant explorations on a yacht outfitted by the wealthy Alison V. Armour, who had led archaeological expeditions.

Received for publication 30 Mar. 1992.

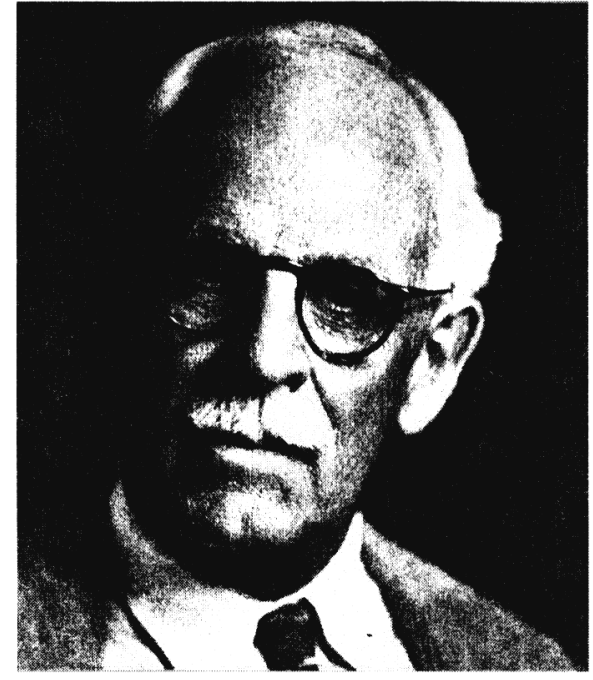

Gilbert Grosvenor, editor of The National Geographic, invited Fairchild to speak to the National Geographic Society. Alexander Graham Bell was present at the lecture, as his older daughter was Grosvenor's wife. This meeting subsequently led to a friendship between Fairchild and Bell's younger daughter Marion. They were married in 1905 and lived in Maryland in their home, "In the Woods," which Lathrop named.The Fairchilds were well suited for each other, sharing an interest in plants, travel, and intellectual challenges.

In 1915 Fairchild established the Plant Introduction Garden near Miami. After World War I, the garden was moved to the site of the former Chapman Airfield and was renamed the Chapman Field Plant Introduction Garden.

Fairchild and his wife fell in love with the climate and plants of this subtropical area and purchased the old Galt Simmonds estate on the bayshore in Coconut Grove. The estate consisted of several buildings similar to the groups of houses that make up family homes in Java, and they named their home "The Kampong." Following his retirement from the USDA in 1933, Fairchild spent his winters at The Kampong and his summers at the Bell home in Baddeck, Nova Scotia. The Kampong continues to be a horticultural showplace for many of the tropical plants that Fairchild collected.
Fairchild's four books-Exploring for Plants (1930), The World Was My Garden (1943), Garden Islands of the Great East (1944), and The World Grows Around My Door (1947) detail his experiences in plant exploration and his contributions to the expansion of horticulture through the introduction of foreign plants.

Inspired after reading Exploring for Plants, Col. Robert H. Montgomery and his wife donated plants and money for the initial development of what is now the Fairchild Garden in Miami. The garden, known throughout the world for its collection of tropical and subtropical plants and for the botanical research conducted there, stands as a lasting tribute to David Fairchild.

Many honors came to Fairchild during his life-honorary degrees, medals, and election to various offices in scientific organizations. The respect he received from the scientific community is perhaps best exemplified by the many famous scientists, students, and friends who visited him during his retirement. He died at his home in Coconut Grove, Fla., on 6 Aug. 1954.

Fairchild will live long in the memory of scientists and others who have profited not only from his scientific contributions, but also from his philosophy of life and zestful enthusiasm for all around him.

\section{References}

Douglas, M.S. 1973. Adventure in a green worldThe story of David Fairchild and Barbour Lathrop. Field Res. Projects, Coconut Grove, Fla.

Fairchild, D. 1930. Exploring for plants. Macmillan, New York.

Fairchild, D. 1943. The world was my garden. Scribners \& Sons, New York.

Fairchild, D. 1944. Garden islands of the great east. Scribners \& Sons, New York.

Fairchild, D. 1947. The world grows round my door. Scribners \& Sons, New York.

Kay, E.D. 1964. David Fairchild-A recollection. Huntia 1:71-78.

Lawrence, G.H.M. 1964. A bibliography of the writings of David Fairchild. Huntia 1:79-102.

Williams, B. and S. Epstein. 1961. Plant explorerDavid Fairchild. Messner, New York. 